\title{
IRONI PERDAGANGAN MANUSIA BERKEDOK PENGIRIMAN "PAHLAWAN DEVISA NEGARA"
}

\author{
Mustika Prabaningrum Kusumawati \\ Fakultas Hukum Universitas Islam Indonesia \\ Jalan Taman Siswa No. 158 Yogyakarta \\ +6285702444909/mustika.praba@gmail.com
}

\begin{abstract}
Human trafficking disguise as shipping heroes of countrie's foreign exchange occured because the government does not exercise its function properly. The existence of Indonesia's Criminal Law Book (KUHP), The Act of 39 Year 2004 About Placement and Protection of Indonesian Labor, The Act of 21 Year 2007 About Eradication of Human Trafficking, as well as several other laws are expected to be optimally applied. In connection with the shipment of labors that disguise as heroes of countrie's foreign exchange, it is urgent to prevent it comprehensively and integrally which covers: direct prevention, indirect prevention, prevention with some environment restoration, and prevention through the attitude upgrading.
\end{abstract}

Keywords: Human Trafficking; Indonesian Labor; Criminal Law

\begin{abstract}
Abstrak
Maraknya perdagangan manusia yang berkedok pengiriman pahlawan devisa negara terjadi karena negara tidak menjalankan fungsinya dengan baik. Keberadaan KUHP, Undang-Undang Nomor 39 Tahun 2004 tentang Penempatan dan Perlindungan TKI, Undang-Undang Nomor 21 Tahun 2007 tentang Pemberantasan Tindak Pidana Perdagangan manusia serta beberapa undang-undang lainnya diharapkan dapat maksimal diterapkan. Sehubungan dengan beberapa modus perdagangan manusia khususnya yang berkedok pengiriman pahlawan devisa negara maka dibutuhkan upaya berupa pencegahan, penangan serta penanggulangan yang sifatnya komprehensif dan integral yang mencakup: pencegahan langsung, pencegahan tidak langsung, pencegahan melalui perbaikan lingkungan, pencegahan melalui perbaikan perilaku.
\end{abstract}

Kata Kunci: Perdagangan Manusia; Tenaga Kerja Indonesia; Hukum Pidana

\section{A. PENDAHULUAN}

Pahlawan diartikan sebagai seorang yang menonjol karena keberanian dan pengorbanannya dalam membela kebenaran; pejuang yang gagah berani (Anton, 1988: 1104). Sedangkan devisa diartikan sebagai alat pembayaran luar negeri yang dapat ditukarkan dengan uang luar negeri (Anton, 1988: 1104). Maksud dari frasa “... yang dapat ditukarkan dengan uang luar negeri" adalah berupa emas, surat 
berharga, mata uang asing dan lain sebagainya. Sedangkan yang dapat dibayar dengan menggunakan devisa adalah pada saat membiayai perdagangan luar negeri yang berupa impor barang dan jasa; membayar pokok utang, cicilan utang luar negeri; membiayai pembinaan dan pemeliharaan hubungan luar negeri yaitu untuk kedutaan, konsulat, biaya kontingen olahraga, misi kebudayaan ke luar negeri; mengatasi kesulitan perekonomian negara dalam kaitannya dengan pembayaran luar negeri; memudahkan terjadinya transaksi dalam perdagangan internasional.

Semakin banyak mata uang asing yang ditukarkan dalam bentuk mata uang rupiah maka akan memberikan dampak pada 2 (dua) aspek yaitu:

1. Bertambahnya mata uang asing di kas negara, sehingga mata uang asing ini disebut sebagai sumber devisa;

2. Kebutuhan terhadap rupiah meningkat, jika dibiarkan terus demikian, maka sesuai hukum "supply and demand", nilai rupiah akan menguat dibanding mata uang asing.

Sebagai gambaran lebih jelasnya, Tenaga Kerja Indonesia (TKI) kita yang bekerja di luar negeri mendapatkan penghasilan dalam bentuk mata uang asing sesuai dengan negara tempat ia bekerja yang kemudian sebagian besar dari TKI kita mengirimkan penghasilannya tersebut kepada keluarganya di Indonesia. Oleh karena mata uang yang didapatkan para TKI kita adalah mata uang asing, maka haruslah dikonversikan terlebih dahulu ke mata uang rupiah yang lalu diproses dimana mata uang asing ini disimpan oleh pihak bank kemudian barulah dapat digunakan untuk melakukan pembayaran luar negeri oleh negara kita.

Mekanisme transfer sumber daya (resource) dari para TKI ini dikenal dengan remitansi (worker's remittances) yang pada negara berkembang seperti Indonesia, karena alirannya yang cukup substansial maka remitansi menjadi sumber devisa alternatif yang digunakan sebagai sumber pembiayaan eksternal disamping pinjaman pemerintah dan investasi swasta (Ratha, 2003: 157-175). Remitansi juga menjadi sumber penerimaan devisa (foreign exchange earnings) yang penting bagi banyak negara, sehingga turut mempengaruhi posisi neraca pembayaran (balance of payments) negara penerimanya.

Oleh sebab itu, semakin banyak penghasilan yang dibawa oleh para TKI yang kembali ke tanah air maka akan memberikan dampak yang besar pula dalam memberikan kontribusi terhadap pertumbuhan devisa Negara. Apabila devisa negara meningkat, maka akan berdampak besar pada pertumbuhan ekonomi bangsa Indonesia. Itu sebabnya peran dari buruh migran sangat penting. Sebagai salah satu negara yang banyak mengirim tenaga kerja ke luar negeri, Indonesia juga menikmati aliran masuk remitansi. Selain itu, setiap tahun jumlah remitansi yang masuk akan semakin bertambah (Barajas, 2010: 287).

Seperti dua sisi mata uang, keberadaan pahlawan devisa negara di satu sisi memang memberikan dampak positif terhadap pertumbuhan devisa namun di sisi 
lain justru diri mereka sendirilah yang dikorbankan begitu saja. Betapa tidak, banyak sekali kasus-kasus yang menjerat para pahlawan devisa negara kita terutama berkaitan dengan kasus yang termasuk kategori perdagangan manusia. Berbagai macam modus yang digunakan oleh oknum tidak bertanggungjawab dilakukan demi menjebak para calon tenaga kerja Indonesia untuk bersedia diberangkatkan secara illegal. Di samping itu faktor kemiskinan dirasa menjadi pemicu utama para calon tenaga kerja Indonesia tanpa berfikir panjang bersedia dikirim ke berbagai negara tujuan. Pertanyaan besar pun muncul, apakah faktor utama penyebab terjadinya perdagangan manusia berkedok pengiriman pahlawan devisa negara.

\section{B. PEMBAHASAN}

Sudah menjadi kodrat alam, bahwa manusia sejak dahulu kala selalu hidup bersama-sama dalam suatu kelompok (zoon politicon). Dalam kelompok manusia itulah mereka berjuang bersama-sama mempertahankan hidupnya mencari makan, melawan bahaya dan bencana serta melanjutkan keturunannya. Mereka berinteraksi, mengadakan hubungan sosial. Untuk mempertahankan hak mereka untuk dapat hidup di tempat tinggal tertentu yang mereka anggap baik untuk sumber penghidupan, diperlukan seseorang atau sekelompok kecil orang-orang yang ditugaskan mengatur dan memimpin kelompoknya. Kepada pemimpin kelompok inilah diberikan kekuasaan-kekuasaan tertentu dan kelompok manusia tadi diharuskan menaati peraturan-peraturan perintah pemimpinnya (Kansil, 2001: 133).

Negara dipersamakan artinya dengan istilah state (dalam Bahasa Inggris), staat (dalam Bahasa Jerman), memiliki dua arti. Pertama, negara adalah sebuah tatanan masyarakat atau wilayah yang merupakan satu kesatuan politis. Sebagai contoh, negara Malaysia, Jepang, Indonesia dan lain sebagainya. Kedua, negara merupakan lembaga pusat yang menjamin kesatuan politis itu, yang menata dan dengan demikian menguasai wilayah politis tersebut (Franz, 1991: 170).

Menurut Plato, negara adalah suatu tubuh yang senantiasa maju, berevolusi dan terdiri dari orang-orang (individu-individu) yang timbul atau ada karena masing-masing dari orang itu secara sendiri-sendiri tidak mampu memenuhi kebutuhan dan keinginannya yang beraneka ragam, yang menyebabkan mereka harus bekerja sama untuk memenuhi kepentingan mereka bersama. Kesatuan inilah yang kemudian disebut masyarakat atau negara (Soehino, 1980: 17). Menurut Thomas Hobbes bahwa negara adalah suatu tubuh yang dibuat oleh orang banyak beramai-ramai, yang masing-masing berjanji akan memakainya menjadi alat untuk keamanan dan pelindungan mereka.

Sesuai dengan pelaku utama hubungan internasional adalah negara, maka yang menjadi perhatian utama hukum internasional adalah hak dan kewajiban serta kepentingan negara. Negara sebagai salah satu subjek hukum internasional, bahkan 
menjadi subjek hukum internasional yang pertama dan utama serta terpenting (par excellence). Negara menjadi subjek hukum internasional yang pertama-tama, sebab kenyataan menunjukkan bahwa yang pertama-tama yang mengadakan hubungan internasional. Negara sebagai suatu kesatuan politik dalam hukum internasional yang juga sifatnya keterutamaannya maka suatu negara harus memiliki unsur-unsur tertentu berdasarkan hukum internasional. Aturan hukum internasional yang disediakan masyarakat internasional dapat dipastikan berupa aturan tingkah laku yang harus ditaati oleh negara apabila mereka saling mengadakan hubungan kerjasama (Burhan, 1990: 12).

Indonesia merupakan negara hukum. Hal ini berdasarkan tujuan negara Indonesia yang dituangkan dalam alinea IV Pembukaan UUD 1945, nampak jelas bahwa negara Indonesia menganut sistem negara hukum dalam arti luas dimana negara hukum kesejahteraan (welfare state) sehingga tanggung jawab negara tidak hanya melindungi (protecting) tetapi juga sebagai alat pelayanan (service agency) dan penyelenggara kesejahteraan (welfare) (Any, 2013). Secara teori, menurut Bagir Manan tujuan negara hukum adalah menjunjung tinggi adanya sistem hukum yang menjamin kepastian hukum dan perlindungan terhadap hak-hak rakyat serta melaksanakan kesejahteraan umum. Teori ini mengambil esensi bahwa hukum adalah supreme dan sebuah kewajiban bagi penyelenggara negara untuk tunduk pada hukum. Tidak ada kekuasaan di atas hukum (Bagir, 2006: 9-10).

Negara hukum pada prinsipnya menghendaki segala tindakan atau perbuatan penguasa mempunyai dasar hukum yang jelas atau legalitasnya baik berdasarkan hukum tertulis maupun hukum yang tidak tertulis. Ajaran negara hukum menurut Krebbe disebutkan yakni "Negara bertujuan menyelenggarakan ketertiban hukum dan berpedoman pada hukum. Dalam negara hukum, segala kekuasaan alat-alat pemerintahannya didasarkan pada hukum. Semua orang tanpa kecuali, harus tunduk dan taat kepada hukum (Government not by man, but by law/the rule of law). Rakyat tidak boleh bertindak atas kemauan sendiri dan menentang hukum. Di dalam negara hukum, hak-hak rakyat dijamin sepenuhnya oleh negara, sebaliknya rakyat berkewajiban mematuhi seluruh peraturan pemerintah/ negaranya" (Manan, 2006: 31).

Philipus M Hadjon sebagaimana dikutip Any Suryani $H$ memberikan pernyataan dalam konteks negara Indonesia di mana adanya pengakuan terhadap harkat martabat manusia dalam negara hukum Indonesia yang secara intrinsik melekat pada Pancasila dan bersumber pada Pancasila. Masih mengacu pada Pancasila, Philipus M Hadjon merumuskan elemen unsur-unsur negara hukum Pancasila terdiri dari keserasian hubungan antara pemerintah dan rakyat berdasarkan asas kerukunan, hubungan fungsional yang proporsional antara kekuasaan negara, prinsip penyelesaian sengketa secara musyawarah dan peradilan merupakan sarana terakhir dan keseimbangan antara hak dan kewajiban (Manan, 2006: 30). 
Aristoteles mengajarkan tentang pemerintahan berdasarkan kemauan dan cita-cita mayoritas warga. Aristoteles menyatakan bahwa manusia sejak lahir takluk di bawah hukum kodrat yang rasional dan yang iirasional. Hal ini menegaskan bahwa manusia memang ditakdirkan untuk menjadi pemimpin di muka bumi atas makhluk-makhluk ciptaan Tuhan lainnya, karena manusia memiliki akal, budi pekerti dan hati nurani sehingga harus dijaga dan dilindungi sebagai bagian dari pemerintahan HAM (Aristoteles, 1962: 159).

Setiap kaidah/aturan pada umumnya mengatur tingkah laku masyarakat sehingga hukum hanya satu di antara jenis kaidah lainnya yang bersifat mengatur. Secara umum, Radbruch membedakan kaidah atas dua bagian yaitu kaidah alam yang menyatakan tentang apa yang pasti akan terjadi dan merupakan penyesuaian dengan kenyataan yang mengemukakan sesuatu harus ada. Kaidah yang kedua yakni kaidah kesusilaan, yatu kaidah yang menyatakan sesuatu yang belum pasti terjadi atau sesuatu yang seharusnya terjadi. Kaidah kesusilaan merupakan kaidah yang dapat disesuaikan dengan kenyataan. Kaidah ini menggambarkan sesuatu rencana atau keadaan yang ingin dicapai. Radbruch menambahkan bahwa ada kaidah lain selain kaidah alam dan kaidah kesusilaan yakni kaidah kultural yang berada di tengah kaidah alam dan kaidah kesusilaan. Demikian pula dengan pengaturan HAM yang tidak hanya berupa pengakuan alamiah sebagai anugrah Tuhan tetapi harus diimplementasikan dalam hukum positif. Sehingga keberadaan HAM tidak hanya sekedar pengakuan dan perlindungan saja tetapi lebih jauh harus mampu memenuhi rasa keadilan dan kesejahteraan seluruh masyarakat yakni adanya keseimbangan antara hak dan kewajiban (Ahmad, 2008: 33).

HAM yang sering disebut dengan hak kodrati, hak dasar (natural rights), dalam bahasa Belanda dikenal dengan istilah ground rechten, mensen rechten, rechten van deen mens, merupakan pengakuan atas adanya hak manusia, hak dalam bermasyarakat dan berhubungan dengan kewajiban asasi manusia. Istilah natural rights kemudian berkembang menjadi human rights yang mengandung arti persamaan di depan hukum (equality before the law). Soedjono Dirdjosisworo mengartikan HAM sebagai seperangkat hak yang melekat pada hakikat dan keberadaan manusia sebagai makhluk Tuhan Yang Maha Esa dan merupakan anugerah-Nya yang wajib dihormati, dijunjung tinggi dan dilindungi oleh negara, hukum, pemerintah dan setiap orang demi kehormatan serta perlindungan harkat dan martabat manusia (Soedjono, 202: 33).

Dalam sejarah perdagangan manusia, pada awalnya yang menjadi objek perdagangan manusia adalah perempuan. Pada masyarakat Yunani kuno, perempuan dijadikan transaksi jual beli di pasar-pasar, layaknya seperti dagangan binatang atau barang-barang lainnya. Perkembangan berikutnya wanita di Yunani kuno dijadikan tempat pelampiasan nafsu semata. Perempuan sama sekali tidak berharga. Hal ini dibuktikan dalam legenda terkenal di Yunani, yaitu tentang kisah Dewi Aphrodite. Dewi Aphrodite dengan mudahnya menghianati suaminya yang 
oleh masyarakat Yunani dianggap sebagai Dewa. Dewi Aphrodite melahirkan anak yang bernama Koubid yang dianggap sebagai Dewa Cinta. Dewa Cinta ini lahir dari hasil perselingkuhan Dewi Aphrodite dengan kekasihnya. Legenda ini sangat merendahkan martabat dan moral perempuan, karena merupakan penghianatan moral (Ahsin, 2005: 103). Pada masa lalu, perdagangan manusia merupakan suatu simbol/status sosial, di mana orang yang mempunyai status sosial tinggi (ekonomi dan kekuasaan/politik) dipastikan akan mempunyai budak/budakbelian. Adapun yang dimaksud dengan "budak" adalah orang yang dibeli dan dijadikan budak, hamba, jongos. (Anton, 1988: 103).

Pembahasan mengenai budak dan majikan tidak akan pernah terlepas dari peraturan dan hubungan hukum yang ada. Hal ini didasarkan pada hak-hak serta kewajiban-kewajiban dari kedua belah pihak baik dari segi sosiologis di mana posisi budak selalu dijadikan sebagai objek (bukan subjek) yang mana status sosialnya berada di bawah majikan, didasarkan dari segi ekonomi dimana kondisi budak selalu lebih miskin atau dibawah kemampuan ekonomi majikan, dan didasarkan dari segi yuridis yaitu posisi budak jauh dibawah kekuasaan sang majikan sehingga eksploitasi tidak dapat dihindarkan.

Keadaan yang sangat miris ini terus berkembang sejak zaman penjajahan sampai pada tahun 1854 pada saat pemerinta atau raja dan Parlemen Belanda mengundangkan Wet (Undang-undang) Belanda No. 2 Tahun 1854 (Staatblad No.2 Tahun 1855) yaitu Reglement op het Beleid der Regering van Nederlands Indie (RR) yaitu dalam Pasal 169 yang menentukan paling lambat 1 Januari 1860 perbudakan di Hindia Belanda sudah harus dihapus total. Upaya ini kemudian diimplementasikan dalam Wetboek van Strafrecht (KUHP Hindia Belanda), meskipun baru sebatas peraturan normatif saja, karena dalam kenyataannya belum dijalankan (Gandhi, 2006: 47). Hal ini disebabkan pemerintah kolonial di Hindia Belanda masih melaksanakan perbudakan meskipun dengan alasan-alasan politis tertentu.

Tindak pidana perdagangan manusia meskipun telah diatur di dalam berbagai peraturan hukum yang ada, namun tindakan untuk mengingkari keberadaan HAM masih sering terjadi justru semakin meningkat. Salah satu bentuk pelangaran HAM yang dewasa ini marak terjadi yaitu pengiriman TKI ke luar negeri sebagai bentuk eksploitasi (baik jasmani maupun seksual) dan perdagangan manusia. Dapat dilihat bahwa bentuk pelanggaran HAM di sini adalah pengiriman TKI berkedok eksploitasi dan perdagangan manusia yang merupakan bentuk modern dari perbudakan.

Tindak pidana perdagangan manusia merupakan salah satu jenis dari tindakan/perbuatan yang dinamakan kejahatan. Kejahatan dalam istilah yuridis disebut tindak pidana yang mana menurut Saparinah Sadli kejahatan ini merupakan salah satu bentuk "perilaku menyimpang" (Saprinah, 1976: 56). Tindak pidana perdagangan manusia atau sering disebut dengan trafficking, berasal dari Bahasa 
Inggris traffic yaitu commerce; trade; the sale or exchange of such things as merchandise, bills and money (Bryan, 2009: 1634). Dalam Bahasa Indonesia diterjemahkan menjadi lalu lintas; perdagangan; berdaganag; tukar menukar. Istilah ini kemudian diartikan sebagai perdagangan. Kemudian istilah trafficking menurut Black's Law Dictionary disebutkan sebagai the act of transporting, trading, or dealing, especially in people or illegal goods. Sedangkan Human Trafficking yaitu the illegal recruitment, transportasion, transfer, harboring, or receipt of a person, one from another country, with the intent to hold the person captive or exploit the person for labour, services, or body parts. Human Trafficking offenses include forced prostitution, force marriages, sweat shop labour, slavery, and harvesting organs from unwilling donor-Also termed trafficking in persons (Bryan, 2009: 1635).

Indonesia merupakan salah satu negara di dunia yang memiliki jumlah penduduk yang tinggi. Penduduk yang tinggi ini dapat dilihat sebagai beban dan potensi bagi pembangunan. Semua upaya pembangunan, kapan dan di manapun selalu diarahkan untuk meningkatkan kesejahteraan penduduk, menurunkan jumlah penduduk miskin, pengangguran serta mengurangi tingkat ketimpangan sosial, dan ekonomi di antara kelompok dalam masyarakat. Berdasarkan data Badan Pusat Statistik (BPS) (www.bps.go.id), jumlah penduduk angkatan kerja baik yang terdiri dari penduduk yang bekerja maupun yang pengangguran dari tahun 20082017 menunjukkan peningkatan yang signifikan dari tahun ke tahun.

Secara teoritis, pertumbuhan ekonomi pada suatu wilayah atau negara akan selalu diikuti dengan perubahan-perubahan pada berbagai sektor. Sebagai salah satu contoh perubahan yang paling nampak dan paling cepat adalah pembangunan yang berimbas pada pola konsumtif yang berhubungan dengan pertumbuhan ekonomi suatu wilayah atau negara. Keterbatasan sumber daya khususnya ekonomi dalam suatu wilayah atau negara akan mengakibatkan terjadinya perpindahan atau yang lebih dikenal dengan istilah migrasi di mana migrasi ini tidak hanya antar wilayah dalam negeri saja tetapi sudah meluas hingga ke luar negeri demi memperbaiki kondisi ekonomi.

Sejalan dengan semakin meningkatnya tenaga kerja yang ingin bekerja di luar negeri dan besarnya jumlah TKI yang sekarang ini bekerja di luar negeri, meningkat pula kasus perlakuan yang tidak manusiawi terhadap TKI yang bekerja di luar negeri (Prabaningrum, 2016: 162). Situasi arus migrasi khususnya migrasi ke luar negeri yang semakin hari semakin meningkat justru dimanfaatkan dan disalahgunakan oleh pihak-pihak yang tidak bertanggungjawab dengan modus akan mencarikan pekerjaan disertai dengan janji akan diberikan pendapatan yang sangat besar sehingga para calon tenaga kerja tertarik untuk direkrut.

Dalam prakteknya, para tenaga kerja, buruh ataupun istilah lainnya dapat berasal dari luar daerah atau antar wilayah bahkan antar negara sehingga muncullah istilah migrasi ini. Migrasi merupakan suatu aktivitas perpindahan 
penduduk yang dilakukan untuk tujuan ekonomi produktif dan berlangsung tanpa melihat batasan identitas politik, sosial, maupun kultural (Held, 2005: 17). Pola migrasi dapat terjadi melalui 2 (dua) jalur, yakni jalur resmi dan jalur tidak resmi. Pada prakteknya tidak sedikit dijumpai animo calon tenaga kerja Indonesia yang terperangkap iming-iming prosedur instan dan penghasilan besar oleh calo melalui jalur tidak resmi.

Dengan jumlah penduduk Indonesia yang sangat banyak dan berbanding terbalik dengan jumlah lapangan pekerjaan yang tersedia, mau tidak mau menjadi salah satu faktor pendorong banyaknya minat warga negara Indonesia untuk mencari pekerjaan dan penghasilan di luar negeri. Indonesia melalui ketentuan Pasal 27 ayat (2) UUD 1945 menjamin tiap-tiap warga negara berhak atas pekerjaan dan penghidupan yang layak bagi kemanusiaan. Ayat ini memberikan pengakuan dan jaminan bagi seluruh warga negara Indonesia untuk mendapatkan pekerjaan dan mencapai tingkat penghidupan yang layak bagi kemanusiaan. Rendahnya upah TKI menjadi permasalahan tersendiri di samping terbatasnya jumlah lapangan pekerjaan yang ada.

Di dalam ketentuan Pasal 23 ayat (3) Deklarasi Universal HAM PBB disebutkan bahwa setiap orang yang melakukan pekerjaan berhak atas pengupahan yang adil dan baik, yang menjamin kehidupannya bersama dengan keluarga, sepadan dengan martabat manusia dan jika ditambah dengan bantuan-bantuan sosial lainnya. Pasal 31 Undang-Undang Nomor 13 Tahun 2003 tentang Ketenagakerjaan menyebutkan bahwa setiap tenaga kerja mempunyai hak dan kesempatan yang sama untuk memilih, mendapatkan, atau pindah pekerjaan dan memperoleh penghasilan yang layak di dalam atau luar negeri. Pasal 33 UndangUndang Nomor 13 Tahun 2003 tentang Ketenagakerjaan semakin menegaskan bahwa Penempatan tenaga kerja terdiri dari penempatan tenaga kerja di dalam negeri; dan penempatan tenaga kerja di luar negeri. Oleh sebab itu, jelas bahwa setiap warga negara Indonesia di samping terjamin haknya atas pekerjaan namun juga dijamin atas haknya untuk memilih bekerja di dalam negeri ataupun bekerja di luar negeri tanpa kecuali.

Indonesia merupakan salah satu negara pengirim jasa tenaga kerja internasional yang cukup besar di kawasan Asia seperti Hongkong, Taiwan, Malaysia, Singapura, dan beberapa negara tujuan di Timur Tengah seperti Arab Saudi. Kondisi semacam ini menjadikan peluang yang menggiurkan bagi Perusahaan Jasa Tenaga Kerja Indonesia (PJTKI) dalam hal memanfaatkan dan mengakomodir berbagai kepentingan calon TKI yang akan diberangkatkan ke negara tujuan. TKI yang notabene disebut sebagai pahlawan devisa negara justru menjadi tumbal atas peningkatan pendapatan devisa negara Indonesia. Betapa tidak, kenyataan yang tidak dapat dielakkan ialah semakin meningkatnya jumlah TKI yang menjadi korban sejak masa perekrutan, masa kerja yang menjurus ke arah perdagangan manusia, bahkan hingga masa pemulangan ke tanah air. Situasi dan kondisi yang dialami oleh 
korban dapat berupa kondisi ekonomi, sosial, politik, pendidikan, lingkungan. Bahkan kondisi fisik dan mental dapat memberikan pengaruh bagi situasi korban. Korban seperti halnya juga pelaku kejahatan dapat terdiri dari orang perseorangan, kelompok dan juga masyarakat yang mendapatkan kerugian akibat dari perbuatanperbuatan dari pelaku kejahatan yang tidak bertanggung jawab. Kerugian yang diderita oleh korban akan menimbulkan beban serta tekanan psikologis seperti rasa kesal, jengkel, takut yang berkepanjangan, trauma, stress, atau bahkan gangguan kejiwaan (Soedjono, 2002: 5).

Dewasa ini, modus dan bentuk perdagangan manusia sangat beragam baik secara konvensional maupun secara modern dengan menggunakan teknologi yang dilakukan secara orang perseorangan maupun secara terorganisir dalam bentuk korporasi baik dalam lingkup internal negara maupun lingkup antar negara. Para calon TKI yang paling sering menjadi korban perdagangan manusia adalah mereka yang tidak memiliki skill atau kemampuan, berlatar belakang pendidikan yang rendah serta tingkat ekonomi rendah. Mereka inilah yang sangat rentan dijadikan korban perdagangan manusia karena para calo yang akan memberangkatkan mereka secara illegal sangat mudah dalam hal menjerat korban untuk dapat dijadikan sasaran.

Korelasi antara bekerja dengan perdagangan manusia sangat erat yakni kebutuhan akan pekerjaan serta peluang kerja yang tersedia menyebabkan banyaknya orang, termasuk perempuan dan anak-anak terperangkap dalam perdangan orang (trafficking). Kondisi ini didukung pula oleh situasi daerah asal yang tidak memiliki peluang untuk memajukan perekonomian. Selain itu, keberadaan dan peran calo atau tekong yang berubah menjadi trafficker mendapat pengakuan tersendiri dari masyarakat (Sumiati, 2004: 5).

Adapun proses perekrutan, modus serta tujuan dari Tindak Pidana Perdagangan manusia secara umum dapat dirinci sebagai berikut (Henny, 2016: 114):

1. Proses

Dalam bentuk: perekrutan atau pengangkutan atau penampungan atau pengiriman atau pemindahan atau penerimaan seseorang

2. Cara/modus

Dalam bentuk: ancaman kekerasan atau penggunaan kekerasan atau penculikan atau penyekapan atau pemalsuan atau penipuan atau penyalahgunaan kekuasaan atau posisi rentan atau jeratan utang atau memberi bayaran atau manfaat

3. Tujuan

Dalam bentuk: eksploitasi atau mengakibatkan orang tereksploitasi yang meliputi namun tidak terbatas pada pelacuran atau kerja paksa atau perbudakan atau penindasan atau pemerasan atau kekerasan seksual atau transplantasi organ illegal. 
Dari berbagai kejadian dalam pengiriman buruh migran, kerugian dan penderitaan korban disebabkan oleh adanya proses (Gandhi, 2006: 61-65):

1. Perekrutan;

2. Pemalsuan Dokumen;

3. Penyekapan Sebelum Berangkat;

4. Pengangkutan dalam Perjalanan;

5. Di Tempat Kerja;

6. Perjalanan Pulang;

7. Pemulihan/Rehabilitasi.

Kondisi seperti di atas, oleh sebagian orang dirasakan sangat kurang mendapatkan perhatian dari pemerintah. Kalaupun ada, umumnya perhatian pemerintah hanya diberikan terhadap kasus yang sudah mendapatkan perhatian publik khususnya yang terjadi di luar negeri. Hal semacam ini dapat disebabkan oleh (Haris, 2005: 17):

1. Kasus-kasus yang berhubungan dengan kekerasan yang dialami buruh dianggap kurang memiliki nilai politis;

2. Cost politik yang dikeluarkan untuk mengurus persoalan-persoalan pekerja di luar negeri tidak sebanding dengan keuntungan yang didapat;

3. Posisi pekerja Indonesia relatif lemah, baik di dalam maupun di luar negeri, sehingga bargaining power yang telah dilakukan tidak berarti.

Berdasarkan prosedur pengiriman calon tenaga kerja Indonesia (khususnya ke luar negeri) sudah seharusnya melalui tahapan prosedur yang telah ditentukan oleh peraturan perundang-undangan yakni:

1. Undang-Undang Nomor 3 Tahun 1951 tentang Berlakunya Undang-Undang Nomor 23 Tahun 1948 tentang Pengawasan Perburuhan;

2. Undang-Undang Nomor 1 Tahun 1970 tentang Keselamatan Kerja;

3. Undang-Undang Nomor 13 Tahun 2003 tentang Ketenagakerjaan;

4. Undang-Undang Nomor 39 Tahun 2004 tentang Penempatan dan Perlindungan Tenaga Kerja Indonesia di Luar Negeri;

5. Peraturan Menteri Tenaga Kerja Nomor PER-03/MEN/1984 tentang Pengawasan Ketenagakerjaan Terpadu.

Tindak Pidana Perdagangan Orang (TPPO) merupakan tindak pidana yang dianggap baru di dalam sistem hukum Indonesia meskipun praktek tindak pidana ini sudah merajalela sejak lama, karena Undang-Undang Pemberantasan Tindak Pidana Perdagangan Orang (TPPO) ini baru dibuat dan disahkan melalui UndangUndang Nomor 21 Tahun 2007 tentang Pemberantasan Tindak Pidana Perdagangan Orang (TPPO) serta diundangkan pada tanggal 19 April 2007 di dalam Lembaran Negara Tahun 2007 Nomor 58. 
Undang-Undang Nomor 21 Tahun 2007 tentang Pemberantasan Tindak Pidana Perdagangan Orang (TPPO) merupakan bentuk upaya perlindungan hukum baik secara langsung maupun tidak langsung yang tidak hanya diberikan kepada para korban tetapi juga kepada para calon korban agar tidak menjadi korban di kemudian hari. Indonesia telah menunjukkan keseriusan dalam upaya pencegahan dan penanggulangan tindak pidana perdagangan orang dengan meratifikasi Konvensi PBB yakni United Nations Covention Againts Transnational Organized Crime (Konvensi Perserikatan Bangsa-Bangsa Menentang Tindak Pidana Transnasional Yang Terorganisasi) menjadi Undang-Undang Nomor 5 Tahun 2009.

Pengakuan hukum terhadap hak asasi manusia sangat bergantung kepada status manusia secara indiividual yang bertindak sebagai pengemban kodrat kemanusiaan. Akan tetapi, Sudikno Mertokusumo (1999: 41) menyatakan bahwa setiap hubungan hukum yang diciptakan oleh hukum selalu mempunyai dua sisi yang tidak dapat terpisahkan yaitu hak dan kewajiban. Tidak ada hak tanpa kewajiban, demikian juga tidak ada kewajiban tanpa hak.

Agar hak dan kewajiban dapat berjalan dengan baik maka menurut J.G. Steenbeek harus ditentukan dalam suatu konstitusi yang berisi (Steenbeek, 1975: 45):

1. Adanya jaminan terhadap hak-hak asasi manusia dan warga negara

2. Ditetapkan susunan ketatanegaraan suatu negara yang bersifat fundamental;

3. Adanya pembagian dan pembatasan tugas ketatanegaraan yang bersifat fundamental.

C.V. Strong berpendapat bahwa konstitusi yang baik sudah seharusnya mengatur asas-asas (Strong, 1966: 74):

1. Kekuasaan pemerintahan (dalam arti luas)

2. Hak-hak yang diperintah

3. Hubungan antara yang diperintah dan yang memerintah.

Berdasarkan konsep C.V. Strong inilah dapat disimpulkan bahwa posisi dan kedudukan konstitusi dimaksudkan untuk memberikan batasan antara wewenang pemerintah dan penguasa di dalam mengatur jalannya pemerintahan dna menjamin hak-hak rakyat. Oleh karena itu, hubungan antara pemerintah dan rakyat juga harus dibatasi. Pemberian batasan ini dapat dilakukan oleh hukum. Hukum harus dapat menjadi panglima, karenanya hukum harus berwenang memberikan perintah dan bukan justru sebaliknya hukum menjadi budak (takut pada majikan). Untuk itu kedudukan hukum harus lebih tinggi daripada kedudukan pemerintah dan kedudukan lainnya baik politik, ekonomi, kekuasaan, budaya dan sosial. Hukum harus selalu dihormati agar supremasi hukum dapat ditegakkan. Supremasi hukum identik dengan rule of law. Oleh karena itu, supremasi hukum selalu berhubungan dengan negara hukum. 


\section{KESIMPULAN}

Faktor kemiskinan kerap kali memicu orang untuk mengadu nasib ke negara lain dengan harapan dapat memperbaiki kondisi perekonomiannya. Kesuksesan materi yang didapatkan di luar negeri tidak sebanding dengan penderitaan fisik maupun psikologis yang harus mereka tanggung.

Maraknya perdagangan manusia yang berkedok pengiriman pahlawan devisa negara terjadi karena negara tidak menjalankan fungsinya dengan baik. Padahal, Indonesia merupakan negara demokrasi yang menganut prinsip rule of law yang menjunjung tinggi hukum dan HAM. Keberadaan KUHP, Undang-Undang Nomor 39 Tahun 2004 tentang Penempatan dan Perlindungan TKI, Undang-Undang Nomor 21 Tahun 2007 tentang Pemberantasan Tindak Pidana Perdagangan Orang serta beberapa undang-undang lainnya diharapkan dapat maksimal diterapkan.

Sehubungan dengan beberapa modus perdagangan orang khususnya yang berkedok pengiriman pahlawan devisa negara maka dibutuhkan beberapa upaya. Usaha-usaha tersebut seperti halnya yang dikemukakan oleh Gosita (2004: 14-16), berupa pencegahan, penanganan serta penanggulangan yang sifatnya komprehensif dan integral yang mencakup (Gosita, 2004: 14-16):

1. Pencegahan langsung

Dilakukan sebelum terjadinya suatu kejahatan dan dapat dirasakan serta diamati dengan cara:

a. Pengamatan terhadap objek tindak pidana;

b. Pemberian pengawalan/ penjaga;

c. Mengurangi/menghilangkan kesempatan untuk berbuat/ bertindak;

d. Memperbaiki lingkungan (baik struktur sosial, struktur ekonomi, budaya, moral/ nilai, maupun struktur keamanan);

e. Pencegahan terhadap penyebab terjadinya tindak pidana;

f. Kriminalisasi atau pembaharuan sistem hukum;

2. Pencegahan tidak langsung

Dilakukan sebelum atau sesudah kejadian kriminalitas, meliputi:

a. Penyuluhan hukum;

b. Pembuatan peraturan;

c. Pemberian pendidikan dan pelatihan kepada masyarakat;

d. Pengawasan dan penjagaan terhadap korban dan/atau calon korban.

3. Pencegahan melalui perbaikan lingkungan

Dilakukan sebelum atau sesudah kejadian kriminalitas, meliputi:

a. Perbaikan sistem pengawasan;

b. Perencanaan sistem perkotaan;

c. Penghapusan kesempatan melakukan perbuatan kriminal.

4. Pencegahan melalui perbaikan perilaku

Dilakukan sebelum atau sesudah kejadian kriminalitas, meliputi:

a. Pemberian imbalan kepada pelaku yang sesuai dengan hukum; 
b. Penghapusan imbalan yang menguntungkan dari pelaku kriminalitas;

c. Patroli polisi;

d. Pengikutsertaan masyarakat;

e. Pendidikan bagi korban dan calon korban;

f. Pengadaan/ pemberian asuransi;

g. Penguatan ikatan sosial pada masyarakat.

Oleh sebab itu, tidak cukup kiranya apabila hanya melihat dari sisi pertanggungjawaban pemerintah semata. Akan tetapi juga harus melihat dari sisi pribadi para calon TKI dimana kesadaran para calon TKI akan pentingnya mengikuti alur prosedur untuk menjadi TKI yang legal sesuai dengan aturan yang ada, akan memberikan dampak positif terhadap berkurangnya angka perdagangan manusia yang berkedok pengiriman jasa TKI ke luar negeri. Tidak dapat dipungkiri bahwa alur prosedur yang relatif instan, murah dan cepat menjadi salah satu primadona yang menggiurkan bagi calon TKI yang akan dijadikan korban perdagangan orang melalui kedok pengiriman jasa TKI ke luar negeri.

Dibutuhkan kerjasama yang seiring dan seimbang antara pemerintah dan calon TKI untuk sama-sama menyadari bahwa pemerintah bertanggungjawab terhadap jaminan penempatan dan perlidungan TKI di luar negeri serta calon TKI juga bertanggungjawab untuk tunduk dan patuh terhadap prosedur yang harus dilalui untuk menjadi seorang TKI. Tanpa kesadaran dari kedua belah pihak, saya rasa aturan yang telah dibuat sebaik apapun itu, pasti tetap tidak akan berfungsi dengan maksimal.

\section{DAFTAR PUSTAKA}

\section{a. Buku}

Ali, Ahmad (2008). Menguak Tabir Hukum, Bogor: Ghalia Indonesia 2008.

Arief, Gosita (2004). Masalah Korban Kejahatan (Kumpulan Karangan), Jakarta: PT. Bhuana Ilmu Populer Kelompok Gramedia.

Aristoteles (1962). The Politics, United Kingdom: Oxford University Press.

Burhan, Mohd Tsani (1990). Hukum dan Hubungan Internasional, Yogyakarta: Liberty.

Dirdjosisworo, Soedjono (2002). Pengadilan Hak Asasi Manusia, Bandung: Citra Aditya Bakti.

Dirdjosisworo, Soedjono (2002). Respon Terhadap Kejahatan, Bandung: STHB Press.

Garner, Bryan A. (2009). Blacks Law Dictionary, Ninth Edition, USA: West Group St Paul Minn.

Haris, Abdul (2005). Gelombang Migrasi dan Jalur Perdagangan Manusia, Yogyakarta: Pustaka Pelajar.

Kansil, C.S.T. (2001). Ilmu Negara Umum dan Indonesia, Jakarta: PT Pradnya Paramita. 
Lapian, L.M. Gandhi \& Geru, Hetty A. (2006). Trafficking Perempuan dan Anak Penanggulangan Komprehensif Studi Kasus: Sulawesi Utara, Jakarta: Yayasan Obor.

Magnis, Franz (1991). Etika Politik, Prinsip-Prinsip Moral Dasar Negara Modern Jakarta: Gramedia Pustaka Utama.

Manan, Bagir (2006). Lembaga Kepresidenan, Yogyakarta: FH UII Press.

Mertokusumo, Sudikno (1999). Mengenal Hukum Suatu Pengantar, Yogyakarta: Liberty.

Moeliono, Anton M. (ed), (1988). Kamus Besar Bahasa Indonesia, Jakarta: Balai Pustaka.

Muhammad, Ahsin Sakho; Nasution, Sayuti Anshari; Suratmaputra, Ahmad Munif (t.t.). Ensiklopedi Al-Quran Jilid 3, Jakarta: Kharisma Ilmu.

Nuraaeny, Henny (2016). Tindak Pidana Perdagangan Orang Dalam Perspektif Hak Asasi Manusia, Jakarta: Raja Grafindo Persada.

Sadli, Saparinah (1976). Persepsi Sosial Mengenai Perilaku Menyimpang, Jakarta: Bulan Bintang.

Sahala, Sumiati (2004). Laporan Akhir Penulisan Karya Ilmiah: Masalah Perdagangan Anak dan Wanita Berdasarkan Protokol Konvensi T.O.C. Jakarta: Badan Pembinaan Hukum Nasional, Departemen Hukum Dan HAM RI.

Soehino, (1980). Ilmu Negara, Yogyakarta: Liberty.

Soemantri, Sri (1979). Prosedur dan Sistem Konstitusi, Bandung: Alumni.

Strong, C.V. (1966). Modern Politic Constitution, London: Sidgwik dan Jackson Limited.

\section{b. Jurnal, Tesis/Disertasi, dan Laporan Penelitian}

Kusumawati, Mustika Prabaningrum (2016). Nasib TKI di Tengah Keberadaan Undang-Undang Nomor 34 Tahun 2004. Jurnal Novelty, 7(2).

Sahala, Sumiati (2004). Laporan Akhir Penulisan Karya Ilmiah: Masalah Perdagangan Anak dan Wanita Berdasarkan Protokol Konvensi T.O.C. Jakarta: Badan Pembinaan Hukum Nasional, Departemen Hukum Dan HAM RI.

Suryani, Any (2013). Tanggung Jawab Negara terhadap Korban Perdagangan Orang (Trafficking) dari Perspektif Hak Asasi Manusia. Disertasi Tidak Terpublikasikan.

\section{c. Peraturan Perundang-Undangan}

Kitab Undang-Undang Hukum Pidana (KUHP).

Undang-Undang Nomor 21 Tahun 2007 tentang Pemberantasan Tindak Pidana Perdagangan Orang.

Undang-Undang Nomor 13 Tahun 2003 tentang Ketenagakerjaan.

Undang-Undang Nomor 39 Tahun 2004 tentang Penempatan dan Perlindungan Tenaga Kerja Indonesia di Luar Negeri.

Peraturan Menteri Tenaga Kerja Nomor PER-03/MEN/1984 tentang Pengawasan Ketenagakerjaan Terpadu. 